\title{
Determinants of Banking Efficiency for Commercial Banks in Indonesia
}

\author{
Heti Suryani Fitri Sulaeman', Sri Mulyantini Moelyono' ${ }^{1}$ Jubaedah Nawir ${ }^{1}$
}

ABSTRACT

\begin{abstract}
This study analyzes internal and external factors that affect banking efficiency by using quarterly data for 2013-2017. The sample includes conventional and Islamic commercial banks. Hypothesis testing uses the Tobit regression model. The results show that the loan to deposit ratio/ financing to deposit ratio (LDR/FDR), the net interest margin/net operating margin (NIM/NOM), the capital adequacy ratio (CAR), and economic growth have a significantly positive effect on the efficiency of commercial banks. The NIM/NOM, the BI-rate, and the inflation have no effect on the efficiency of commercial banks. According to another analysis, factors that influence the efficiency of the results show that in conventional commercial banks, the LDR, the CAR, economic growth, and inflation have a significantly positive effect on the efficiency of conventional commercial banks. In contrast, the NIM has a significantly negative effect. Meanwhile, for Sharia commercial banks, the FDR, NPF, the CAR, economic growth and inflation have a significantly positive effect, and the Bl-rate has a significantly negative effect.
\end{abstract}

KEY WORDS: $\quad$ Bank efficiency, Data Envelopment Analysis (DEA), Commercial Banks

JEL Classification: G21, P43, E50

'Universitas Pembangunan Nasional "Veteran" Jakarta, Indonesia

\section{Introduction}

The efficiency and resilience of the banking industry has an important role considering that a high level of efficiency is an indicator of increasing banking competitiveness. The continuity of banking operations depends on their ability to maintain competitiveness as reflected by levels of operational efficiency. Some external factors that can improve the efficiency of the Indonesian banking system include the implementation of the ASEAN Economic Community (MEA) and the ASEAN Banking Integration Framework (ABIF).

Correspondence concerning this article should be addressed to: Heti Suryani Fitri Sulaeman, Universitas Pembangunan Nasional "Veteran" Jakarta, Jl. Rs. Fatmawati No 1, Pondon Labu, Jakarta, Indonesia. E-mail: hetisuryanifitri@upnvj.ac.id
The ability to produce output that is maximized with existing inputs is a measure of expected performance. When measuring efficiency, banks are faced with conditions for obtaining optimal levels of output from existing inputs or from a minimum level of input with a certain level of output (Hadad et al., 2008).

Many bank efficiency studies have been carried out given the efficiency of banks moving dynamically in line with business environments, and so the efficiency of banks will continue to be interesting to study. However, in estimating banking efficiency, there are disagreements on the determination of input-output variables and regarding the measurement of efficiency. Before addressing research-gaps related to current topics, it is important to examine the growth and development of efficiency measures over a period of time. 
The measurement of banking performance based on levels of efficiency can involve the use of various indicators based on a financial statement analysis. From financial statements, a number of financial ratios are used to predict profits and to anticipate future conditions (Halkos \& Tzeremes, 2010). There are some drawbacks associated with using financial statements to assess banking performance and efficiency. Financial ratios do not consider input and output prices or financial ratio choices as subjective performance indicators. Financial ratios only compare performance across periods (Chen, 2002). Weaknesses related to the use of financial ratios to assess performance and efficiency can be overcome by applying nonparametric techniques or data envelopment analysis (DEA). DEA is a technique used to measure the efficiency of various areas of industry (Charnes et al., 2013).

\section{Literature Review}

\subsection{Efficiency and Data of Envelopment Analysis (DEA)}

In general, unit efficiency or production services refer to the comparison of inputs and outputs used in the production of goods or services. Banking efficiency is an important indicator of a bank's best performance value. A bank performing with maximum efficiency is expected to be able to implement banking intermediation functions optimally and to be able to enhance the value of the company.

Farrell (1957) stated that the efficiency of a company is based on two components: technical efficiency and allocative efficiency. Technical efficiency is defined as a company's ability to optimize the use of available inputs with price structures and production technologies. Allocative efficiency is defined as a company's capacity to select a combination of inputs and outputs that minimize costs or maximize profits. A combination of both measures is used to measure economic efficiency.

According to Mardani, Zavadskas, Streimikiene, Jusoh, and Khoshnoudi (2017), the DEA approach shows great promise as an evaluative tool for the analysis of energy efficiency issues, for which production functions between inputs and outputs are virtually absent or extremely difficult to acquire. The banking industry has been the object of DEA analyses by numerous researchers and has likely been the most heavily studied of all business sectors. Various DEA models have been applied in examining performance assessing problems, and banks' complex production processes have further motivated the extension and improvement of DEA techniques (Paradi \& Zhu, 2013). Among such methods, data envelopment analysis (DEA) has been identified as a leading approach. DEA has been successfully applied in many bank branch performance evaluations using traditional intermediation, profitability and production approaches. However, there has been little focus on the assessment of the growth potential of individual branches ( $\mathrm{La}$ Plante \& Paradi, 2015). DEA can be viewed as a tool for multiple-criteria evaluation problems where DMUs are alternatives and where each DMU is represented by its performance in multiple criteria coined/classified as DEA inputs and outputs. A DEA calculates the relative efficiency of each DMU in relation to all other DMUs from observed values for the input and output of each DMU. It also identifies, for inefficient DMUs, the sources and levels of inefficiencies for each input and output (Banker, Charnes, \& Cooper, 1984). The term DEA was first introduced by Charnes, Cooper, and Rhodes (1978) based on Farrell's (1957) research. The basic DEA CCR model was first introduced by Charnes et al. (1978). The model was modified by Banker et al. (1984) and became the BCC model that generates variable results for scale. The CCR model presupposes that there is no significant relationship between the scale of operations and efficiency while assuming a constant result scale (CRS) and providing overall technical efficiency. The CRS assumption is only justified when all DMUs operate at an optimal scale. However, companies or DMUs in practice can face economies or economics of scale. Thus, when one makes a CRS assumption when not all DMUs operate at an optimal scale, steps calculated from technical efficiency will be contaminated with scale efficiency. Banker et al. (1984) extended the CCR model with relaxed CRS assumptions. The resulting BCC model is used to assess the efficiency of DMU characterized by the variable returns scale (VRS).

DEA starts with fractional programming formulations. Assume that there are n DMUs to evaluate. Each consumes a different number of $\mathrm{i}$ inputs and produces a different $r$ output, i.e., DMUj consumes xji of the input to produce YJI of the output. It is assumed that the 
inputs, xji, and the output, YJI, are nonnegative, and each DMU has at least one positive input and output value. The productivity of the DMU can be written as:

$h j=\frac{\sum_{r=t}^{s} u_{r} y_{r j}}{\sum_{i=1}^{m} v_{i} x_{i j}}$

In this equation, $\mathrm{u}$ and $\mathrm{v}$ are weights assigned to each input and output. Using mathematical programming techniques, DEA optimally provides weights subject to the following constraints. The weight for each assigned DMU is subject to a constraint whereby no other DMU has an efficiency level of greater than 1 when it uses the same weight, implying that an efficient DMU will have a ratio value of 1 . The objective function of DMUk is the weighted total output ratio divided by the weighted total input:

$\max h_{0}(u, v)=\frac{\sum_{r=1}^{s} u_{r} y_{r 0}}{\sum_{i=i}^{m} y_{i} x_{i 0}}$

subject to $\frac{\sum_{r=1}^{s} u_{r} y_{r 0}}{\sum_{i=1}^{m} v_{i} x_{i 0}} \leq 1, j=1,2 \ldots, j 0, \ldots, n$,

ur $\geq 0, r=1,2, \ldots, s$,

$v i \geq 0, i=1,2, \ldots, m$,

where h0 is the technical efficiency of DMU0 for estimation; ur and vi are optimized weights; yrj is the output of type $r$ for the $j$-DMU; xij is the observed number of inputs of type-i for $j$, which is DMU; $r$ denotes different outputs $s$; i denotes different inputs $m$; and $j$ denotes different DMUs.

\subsection{Banking Efficiency}

Measuring the level of efficiency of the banking system can help to identify the performance of measured units and if there is some way for the eventual improvement. These measurements may provide valuable information to market regulators and also bank managers for their decision making. Inefficient banks have, in accordance to the article from Fioderlisi, Molyneux and Marques-Ibanez (2010), the tendency to make risky steps, which are dangerous for the entire financial system.

Traditional efficiency is defined as a company's ability to produce certain outputs by using inputs at minimum portions, and hence efficiency is the input level divided by the level of output. Efficiency is one of the performance parameters that theoretically underlies the performance of an organization based on the philosophy that "the ability to produce optimal output with existing inputs is a measure of expected performance" (Endri, 2016).

Amado, Santos and Marques (2012), stated that technical efficiency a component of overall economic efficiency. However, to achieve economic efficiency, a company must be technically efficient. To achieve maximum profits, a company must be able to produce at the optimal level of output with a certain number of inputs (technical efficiency) and must produce outputs of the right combination at a certain price level (allocative efficiency).

The concept of measuring efficiency can be defined by focusing on the input side (input-oriented) or the output side (output-oriented). Both of these approaches are analogous to primal and dual concepts applied with operations research techniques, which are like two sides of the same coin such that the two approaches consistently lead to the same conclusions on the relative efficiency of a company relative to its partners.

Traditional efficiency is defined as a company's ability to produce certain outputs by using inputs at minimum portions, and hence efficiency is the input level divided by the level of output. Efficiency is one of the performance parameters that theoretically underlies the performance of an organization based on the philosophy that "the ability to produce optimal output with existing inputs is a measure of expected performance" However, to achieve economic efficiency, a company must be technically efficient. To achieve maximum profits, a company must be able to produce at the optimal level of output with a certain number of inputs (technical efficiency) and must produce outputs of the right combination at a certain price level (allocative efficiency).

In the banking sector, efficiency measurements are essential to determining the performance of banking systems. Mahyudin (2005) presented three reasons why the study of efficiency in the banking sector is important. First, the banking industry plays a very crucial role in economic development and public welfare. In addition to serving as a producer of financial services, this industry also acts as a driver of economic development and create jobs as a source of community income. In this regard, the banking system is still a 
major intermediating player between parties that need funds to increase the effectiveness and productivity of community financial resources. Second, banking institutions face challenges related to globalization and intensifying international competition. Competition not only occurs among domestic banks but also between domestic and foreign banks. With increasingly open competitive conditions, domestic banks that are less efficient due, for instance, to high operational costs are very likely to be eliminated from the market. Third, concepts and information provided by research results can serve as important inputs for various parties related to the banking sector. Bank leaders can use such results to improve bank performance while investors can use them to make investment decisions. Similarly, monetary and banking authorities have an interest in banking efficiency because the performance of the banking sector can influence the performance of other economic sectors.

The concept of measuring efficiency can be defined by focusing on the input side (input-oriented) or the output side (output-oriented). Both of these approaches are analogous to primal and dual concepts applied with operations research techniques, which are like two sides of the same coin such that the two approaches consistently lead to the same conclusions on the relative efficiency of a company relative to its partners.

In the banking sector, efficiency measurements are essential to determining the performance of banking systems.

\subsection{Determinants of Banking Efficiency}

Empirical studies on determinants of banking efficiency consider specific bank and macroeconomic factors. The Řepková Study (2015) estimates the determinants of efficiency for the Republic of Indonesia's banking sector for 2001-2012. Employing a data envelopment analysis, the researchers estimate the efficiency of the Republican banking sector.

Empirical studies on determinants of banking efficiency consider specific bank and macroeconomic factors. According to Yildirim (2010) Efficient banks are more profitable, and pure technical efficiency and scale inefficiency are positively related to size. The trend in the performance levels over the period suggests that macroeconomic conditions had a profound influence on the efficiency measures.
Determinants of banking efficiency are estimated through a panel data analysis. The capitalization rate, liquidity risk and riskiness of a portfolio have positive impacts on banking efficiency. ROA, interest rates and GDP have a negative impact on efficiency in the CCR model. In the BCC model, liquidity risk and the riskiness of portfolios have a positive impact on efficiency while GDP has a negative impact on efficiency.

Sufian and Noor (2009) show that for their study period, purely technical inefficiencies exceed scale inefficiencies for both MENA and Asian banking sector countries. Banks from the MENA region were found to serve as global leaders by dominating efficiency borders during the studied period. A positive relationship was found between banking efficiency and loan intensity, size, capitalization, and profitability. The empirical results show that banks that are technically more efficient are those with a smaller market share and few nonperforming loans. Garza-García (2012) study entitled Determinants of bank efficiency in Mexico: A two-stage analysis uses a sample of 332 banks operating in Mexico. The results show that GDP increases bank efficiency while the NIM, NPLs and inflation rates reduce bank efficiency. Thus, large and very large banks are more efficient than small and medium-sized banks with small banks being the least efficient. Nonstateowned commercial banks are more efficient than stateowned commercial banks assuming overall efficiency.

Banks with large branch networks and those that have been in existence for a long time are less efficient than other banks (Stewart, Matousek, \& Nguyen, 2016). The level of capitalization, liquidity risk and the riskiness of portfolios have a positive impact on banking efficiency. ROA, interest rates and GDP have a negative impact on efficiency in the CCR model. In the BCC model, liquidity risk and the riskiness of portfolios have a positive impact on efficiency and GDP has a negative impact on efficiency. Other determi-

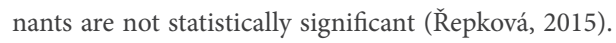
Based on intermediation and production approaches, pre- and postcrisis periods are used to test the relationship between bank size and efficiency scores. The yielded results are compared to traditional performance evaluation ratios, which are calculated for the banking sectors of two countries for different periods (Titko \& Jureviciene, 2014). Crises do not serve as an important source of inefficiency in the Turkish bank- 

We hope to determine whether such tests can support our limited banking study and whether GarzaGarcía's (2012) research study can be validated by the present brief study. Garza-García' s (2012) research study shows that inflation should increase the value of bad credit and render banks inefficient because banks must as a result pay more to manage bad credit.

\section{Methodology}

This study uses the Two Stage Analysis procedure. The first stage of the procedure involves estimating bank efficiency scores through a data envelopment analysis (DEA). The second stage tests factors that influence bank efficiency analyzed separately for BUK and BUS groups because it is assumed that the factors that affect BUK and BUS efficiency are not the same. BUK is based on principles that differ from those of BUS and that are mainly related to interest and profit sharing, but both are applied in commercial banks of the national banking system.

We apply Tobit model regression. We use this method because we use censored data, which denote the value of non-independent variables (Sari \& Saraswati, 2017).

We aim to analyze the influence of internal and external factors as measured by the LDR/FDR, NPLs/ NPF, the NIM/NOM, the CAR, economic growth, interest rates and inflation on the efficiency of conventional commercial banks and Sharia commercial banks in Indonesia using the DEA approach. The sample used in this study includes 8 banks registered at Bank Indonesia (BI) from 2013-2017. Banks shown to be highly efficient via DEA are defined as conventional commercial banks. Data used in this study were obtained from the annual reports of conventional and Islamic commercial banks operating in Indonesia from 2013-2017. We only analyze commercial banks with core capital of $>30$ Trillion Rupiah.

In DEA estimations, inputs and outputs must be defined (Kamarudin et al., 2019). The four main approaches used (intermediation, production, asset and profit approaches) were developed to determine input-output relationships observed from the behaviors of financial institutions. We adopt an intermediation approach and consistent with this approach, we assume that banks collect deposits to change them, to use labor, and provide loans. We employ three inputs
(Third Party Funds, Labor Costs and Assets) and three outputs (loans/financing, Fund Revenue Distribution and fee-based income).

We consider several banking and market factors that can affect the efficiency of commercial banks in Indonesia. These include the loan to deposit ratio/ financing to deposit ratio, nonperforming loans/nonperforming financing, the net interest margin/net operating margin, the capital adequacy ratio, economic growth, the Bi-rate, and inflation.

\subsection{Analysis Method}

We used internal factor variables including the LDR/ FDR, NPLs/NPF, the NIM/NOM, and the CAR and external factors including economic growth, the $\mathrm{BI}$ rate and inflation. The analysis uses a 2-staged analysis where the first stage involves a DEA based on BUK quarterly data for Indonesia, the object of this research for 2013 to 2017. The calculation of efficiency levels via data envelopment analysis uses VRS assumptions (variable returns scale) with outputs based on Sufian and Noor (2009) and Garza-García (2012). For the second stage, we use the Tobit regression model to test determinants of the efficiency of conventional and Islamic commercial banks for 2013 - 2017. Both determinants are derived from internal banks and external variables. The relationship between explanatory factors variables and the efficiency of public banks was tested and analyzed in the second stage using the following formula.

a. The equation for Conventional Commercial Banks (BUK) is as follows:

EFit $=\beta 0+\beta 1(\mathrm{LDR})$ it $+\beta 2(\mathrm{NPL})$ it $+\beta 3(\mathrm{NIM})$ it $+\beta 4(\mathrm{CAR})$ it $+\beta 5(\mathrm{EG})$ it $+\beta 6(\mathrm{BI}$ Rate $)$ it $+\beta 7$ (INF) + uit

b. The equation for Islamic Commercial Banks is as follows:

EFit $=\beta 0+\beta 1($ FDR $)$ it $+\beta 2(\mathrm{NPF})$ it $+\beta 3(\mathrm{NOM})$ it $+\beta 4(\mathrm{CAR})$ it $+\beta 5(\mathrm{EG})$ it $+\beta 6(\mathrm{BI}-\mathrm{Rate})$ it $+\beta 7$ (INF)

+ uit

Information:

$\mathrm{EF} \quad=$ DEA score (level of efficiency)

$\beta 0=$ Constansta

LDR = Loan to Deposit Ratio

FDR = Financing to Deposit Ratio

NPL $=$ Non Performing Loan

$\mathrm{NPF}=$ Non Performing Financing 


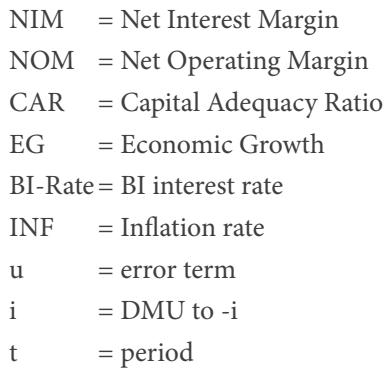

\section{Empirical Results}

\subsection{Phase 1 DEA Analysis}

The statistics given in Table 1 show that in 2013, all conventional commercial banks achieved 100 percent technical efficiency (efficient), including Mandiri Bank in the first and fourth quarters and BRI banks in the first, second and third quarters. As their strongest achievements, BNI banks achieved 100 percent technical efficiency in the first, second, third and fourth quarters while Central Asia Bank (BCA) only achieved 100 percent efficiency (efficient) in the fourth quarter. In 2014, banks that achieved 100 percent technical efficiency (efficient) experienced a decline. Mandiri Bank achieved efficiency in the fourth quarter, and BNI banks achieved 100 percent efficiency in the first, third, and fourth quarters. Likewise, BRI banks achieved 100 percent technical efficiency in the first, second and fourth quarters while BCA did not achieve 100 percent technical efficiency.

In 2015, Mandiri Bank achieved technical efficiency at 100 percent (efficient) in the first and fourth quarters while BNI banks maintained 100 percent technical efficiency in the first, third and fourth quarters. Meanwhile, BRI banks and BCA each achieved technical efficiency at 100 percent (efficient) in one quarter: BRI banks in the fourth quarter and BCA in the third quarter.

In 2016, Mandiri Bank and BRI banks achieved 100 percent technical efficiency (efficient) in the third and fourth quarters. BNI banks achieved 100 percent technical efficiency in the second, third and fourth quarters but did not achieve technical efficiency in each quarter. In 2017, only Mandiri Bank achieved 100 percent technical efficiency in each quarter; BRI banks achieved 100 percent technical efficiency (efficient) in the first, third, and fourth quarters; BCA achieved 100 percent technical efficiency in the fourth quarter; and BNI banks did not achieve technical efficiency in each quarter.

Table 1 also shows that the achievement of average technical efficiency in 4 conventional commercial banks fluctuated each year from 2013-2017. In 2015, it declined to 97 percent from 98 percent measured in 2014. The average achievement of technical efficiency among 4 conventional commercial banks continued to increase to 98 percent in 2016 and then declined again to 97 percent in 2017.

From Islamic Commercial Banking (BUS) quarterly data for Indonesia, the object of this study for 2013 to 2017, we calculated efficiency levels through a Data Enrollment Analysis based on output-oriented VRS (variable returns scale) assumptions.

Based on BUK (Conventional Commercial Bank) quarterly data for Indonesia, the object of this study for 2013 to 2017, we calculated efficiency levels through a Data Enrollment Analysis based on output-oriented VRS (variable returns scale) assumptions.

The statistics given in Table 2 show that in 2013, three Islamic banks, the object of our research, achieved 100 percent technical efficiency (efficient) in each quarter: BSM, BRI Syariah, and BCA Syariah. Meanwhile, BNI Syariah did not achieve 100 percent technical efficiency in each quarter. In 2014, banks that achieved 100 percent technical efficiency experienced a decline. Mandiri Bank achieved efficiency in the fourth quarter and BNI banks achieved 100 percent efficiency in the first, third, and fourth quarters. Likewise, BRI banks achieved 100 percent technical efficiency in three quarters; BRI banks achieved 100 percent technical efficiency in the first, second and fourth quarters; and BCA did not achieve 100 percent technical efficiency.

In 2015, BSM achieved 100 percent technical efficiency in the first and fourth quarters. BNI Syariah and BRI Syariah achieved 100 percent technical efficiency in the fourth quarter. BCA Syariah maintained a 100 percent technical efficiency level each quarter. In 2016, BRI Syariah was the only bank to achieve 100 percent technical efficiency (efficient). BCA Syariah and BRI Syariah achieved 100 percent technical efficiency in the fourth quarter. BCA Syariah achieved efficiency in the second, third and fourth quarters. The other two banks, BSM and BNI Syariah, did not achieve technical effi- 
Table 1. Efficiency Levels of Conventional Commercial Banks

\begin{tabular}{|c|c|c|c|c|c|c|}
\hline Bank & Q & 2013 & 2014 & 2015 & 2016 & 2017 \\
\hline \multirow[t]{4}{*}{ BUK 1} & Q1 & 1 & 0.997525 & 1 & 0.987119 & 1 \\
\hline & Q2 & 0.985046 & 0.969876 & 0.987736 & 0.977044 & 1 \\
\hline & Q3 & 0.972998 & 0.972367 & 0.995683 & 1 & 1 \\
\hline & Q4 & 1 & 1 & 1 & 1 & 1 \\
\hline \multirow[t]{4}{*}{ BUK 2} & Q1 & 1 & 1 & 1 & 0.983832 & 0.990084 \\
\hline & Q2 & 1 & 0.945934 & 0.997596 & 1 & 0.981997 \\
\hline & Q3 & 1 & 1 & 1 & 1 & 0.974608 \\
\hline & Q4 & 1 & 1 & 1 & 1 & 0.965125 \\
\hline \multirow[t]{4}{*}{ BUK 3} & Q1 & 0.989879 & 1 & 0.897102 & 0.969047 & 1 \\
\hline & Q2 & 1 & 1 & 0.957601 & 0.982002 & 0.991194 \\
\hline & Q3 & 1 & 0.964582 & 0.980011 & 1 & 1 \\
\hline & Q4 & 1 & 1 & 1 & 1 & 1 \\
\hline \multirow[t]{4}{*}{ BUK 4} & Q1 & 0.87703 & 0.930309 & 0.880376 & 0.907014 & 0.876209 \\
\hline & Q2 & 0.915596 & 0.914132 & 0.89515 & 0.911958 & 0.87173 \\
\hline & Q3 & 0.936028 & 0.935539 & 0.940064 & 0.905271 & 0.910404 \\
\hline & Q4 & 1 & 0.997797 & 1 & 0.993661 & 1 \\
\hline Average & & 0.979786 & 0.976754 & 0.970707 & 0.976059 & 0.972584 \\
\hline
\end{tabular}

Source: Adapted from "The Determinants of Bank's Efficiency in Indonesia” A. Widiarti, H. Siregar, \&T. Andani. (2015). In Bulletin of Monetary, Economics and Banking, 18(2), 121-146.

ciency in each quarter. In 2017, BSM achieved 100 percent technical efficiency (efficient) in the first quarter and BCA Syariah achieved 100 percent technical efficiency (efficient) in the first, second and third quarters while the other two banks, BNI Syariah and BRI Syariah, did not achieve technical efficiency in any quarter.

Table 2 also shows that the average number of the 4 Islamic banks achieving technical fluctuated each year from 2013-2017. In 2015, the percentage decreased to 96 percent from 98 percent in 2014 and then decreased again in 2016 to 94 percent. The average technical efficiency levels of the 4 Islamic banks continued to increase to 98 percent in 2016 and again to 95 percent in 2017.

\subsection{Phase 2 Analysis using the Tobit Model}

The Tobit regression model was used to examine determinants of the efficiency levels of conventional and Islamic banks for 2013 - 2017. Both determinants derived from internal banks and external variables are shown in the following table.

Our empirical findings show that in addition to the loan to deposit ratio (LDR) factor, other factors including the net interest margin (NIM), capital adequacy ratio (CAR), economic growth and inflation significantly affect the technical efficiency of conventional commercial banks. Meanwhile, the FDR, NPF, the CAR, inflation in economic growth, and interest rates significantly affect the technical efficiency of 
Table 2. Efficiency Levels of Islamic Commercial Banks

\begin{tabular}{|c|c|c|c|c|c|c|}
\hline Bank & Q & 2013 & 2014 & 2015 & 2016 & 2017 \\
\hline \multirow[t]{4}{*}{ BUS 1} & Q1 & 1 & 1 & 1 & 0.96279 & 1 \\
\hline & Q2 & 1 & 1 & 0.980119 & 0.980773 & 1 \\
\hline & Q3 & 1 & 0.968349 & 0.983475 & 0.973218 & 0.995013 \\
\hline & Q4 & 1 & 1 & 1 & 0.981263 & 1 \\
\hline \multirow[t]{4}{*}{ BUS 2} & Q1 & 0.793429 & 0.955591 & 0.892512 & 0.883603 & 0.863156 \\
\hline & Q2 & 0.918431 & 0.950939 & 0.940104 & 0.874423 & 0.891349 \\
\hline & Q3 & 0.935208 & 0.91152 & 0.904216 & 0.886416 & 0.866788 \\
\hline & Q4 & 0.955465 & 0.999453 & 1 & 0.986915 & 0.98683 \\
\hline \multirow[t]{4}{*}{ BUS 3} & Q1 & 1 & 1 & 0.930875 & 0.844881 & 0.880026 \\
\hline & Q2 & 1 & 0.946388 & 0.94246 & 0.913273 & 0.919838 \\
\hline & Q3 & 1 & 0.953891 & 0.901719 & 0.897469 & 0.935013 \\
\hline & Q4 & 1 & 1 & 1 & 1 & 0.950172 \\
\hline \multirow[t]{4}{*}{ BUS 4} & Q1 & 1 & 1 & 1 & 0.931364 & 1 \\
\hline & Q2 & 1 & 1 & 1 & 1 & 1 \\
\hline & Q3 & 1 & 1 & 1 & 1 & 1 \\
\hline & Q4 & 1 & 0.995628 & 1 & 1 & 0.912772 \\
\hline Average & & 0.975158 & 0.98011 & 0.967218 & 0.944774 & 0.95006 \\
\hline
\end{tabular}

Source: Adapted from “The Determinants of Bank's Efficiency in Indonesia” A. Widiarti, H. Siregar, \&T. Andani. (2015). In Bulletin of Monetary, Economics and Banking, 18(2), 121-146.

Islamic commercial banks. Among the seven factors that significantly affect the technical efficiency of commercial banks, the most central factor is the loan to deposit ratio (LDR)/financing to deposit ratio (FDR). Empirical studies of bank liquidity proxied by the loan to deposit ratio (LDR)/financing to deposit ratio (FDR) are in line with results given by Grigorian and Manole (2002) and Credit/Risk Financing is a proxy of nonperforming loans (NPL)/ nonperforming financing (NPF). This is also in line with results given by Ariff and Can (2008), Řepková (2011). that the need for improving risk management and with results for the NIM/NOM given by GarzaGarcía (2012), but results given by Řepková (2011), profitability had a negative impact on efficiency. Our results on the Capital Adecuacy Ratio are in line with results given by Mosko and Bozdo (2015); Řepková (2011). The results given by Barth, Lin, Ma, Seade and Song, (2013); Chortareas, Girardone and Ventour (2012) that tighter restrictions on bank activities are negatively associated with bank efficiency, while greater capital regulation stringency is marginally and positively associated with bank efficiency. Our results on economic growth are in line with GarzaGarcía's (2012) findings, and our results on interest rates are in line with the results of Řepková (2011) interest rate had a negative impact. Finally, our results on subsequent inflation are in line with results given 
Table 3. Tobit Model Results

\begin{tabular}{|c|c|c|c|c|}
\hline & BUK & & BUS & \\
\hline Variable & Coefficient & P-Value & Coefficient & P-Value \\
\hline Constanta (C) & 0,334919 & 0,0005 & 0,663789 & 0,0000 \\
\hline LDR/FDR & 0,721620 & 0,0000 & 0,212782 & 0,0148 \\
\hline NPLs/NPF & $-1,194907$ & 0,0610 & 1,296400 & 0,0006 \\
\hline NIM/NOM & $-1,126841$ & 0,0125 & $-0,107749$ & 0,5725 \\
\hline CAR & 0,485203 & 0,0420 & 0,409067 & 0,0000 \\
\hline Economic Growth & 0,006998 & 0,0329 & 0,020126 & 0,0005 \\
\hline BI Rate & $-0,081848$ & 0,8467 & $-1,849979$ & 0,0161 \\
\hline Inflation & 0,632317 & 0,0372 & 1,941644 & 0,0004 \\
\hline
\end{tabular}

Source: Adapted from "Business efficiency of the commercial banks in ASEAN" by A. Mongid (2016). In Financial Innovations, $13(1), 67-76$.

by Yildirim (2002) that macroeconomic conditions had a profound influence on the efficiency measures.

\subsection{Discussion}

The results of this study indicate that the number of inputs and outputs of conventional and Islamic commercial banks has increased from year to year while the achievement of efficiency in conventional and Islamic commercial banks fluctuated throughout the observation period. On the other hand, several conventional and Islamic commercial banks experience inefficiencies attributed to the suboptimal use of inputs and outputs. Inefficiencies in input (third party funds, labor costs, and total assets) and output variables (credit or financing, income from channeling funds, and feebased income) are observed.

The measurement of technical efficiency tends to be limited to a focus on technical and operational relationships when converting inputs into outputs. Thus, to improve technical efficiency levels, it is only necessary to use an internal micro policy by controlling and allocating resources optimally.

First, the inefficient use of savings inputs in conventional and Islamic commercial banks is reflected in the number of deposit inputs that are still greater than the target. This indicates that its role as an input is not optimal for producing outputs. Excess deposit inputs should in turn be allocated to total assets and to especially productive assets. This can be done by increasing credit or financing (e.g., productive and trade credit) for conventional commercial banks and Mudharabah, Istishna, and Ijarah financing for Islamic commercial banks. Another approach would involve increasing the administrative costs of savings funds to improve bank income. An increase in administrative costs must be accompanied with improvements in the quality of bank services so that such banks can continue to compete.

Second, asset inputs become inefficient when the number of assets used exceeds the required target. Assets are wealth owned by banks and include cash, current accounts for Bank Indonesia, placements with other banks, securities, financing or credit, and fixed assets owned. To address this issue, the proportion of financing accounting for total assets can be increased. Increasing the level of financing will in turn facilitate the intermediation process for both conventional and Islamic commercial banks while increasing operating income and especially that originating from the distribution of funds. While total assets owned by a bank do not need to be reduced, they must be maximized to avoid inefficiencies. The purchasing of fixed assets 



\section{References}

Amado, C. A. F. \& Santos, S. P., \& Marques, P. M. (2012). Integrating the Data Envelopment Analysis and the Balanced Scorecard approaches for enhanced performance assessment. Omega, 40(3), 390-403.

Ariff, M., \& Can, L. (2008).Cost and profit efficiency of Chinese banks: A non-parametric analysis. China Economic Review, 19(2), 260-273.

Banker, R. D., Charnes, A., \& Cooper, W. W. (1984). Some model for estimating technical and scale inefficiencies in data envelopment analysis. Management Science, 30(9), 1078-1092

Barth, J. R., Lin, C., Ma, Y., Seade, J., \& Song, F. M. (2013) Do bank regulation, supervision and monitoring enhance or impede bank efficiency? Journal of Banking \& Finance, 37(8), 2879-2892.

Berger, A. N., \& Mester, L. J. (1997). Inside the black box: What explains differences in the efficiencies of financial institutions. Journal of Banking and Finance, 21, 895-947.

Charnes A., Cooper, W. W., \& Rhodes, E. (1978). Measuring the efficiency of decision making units. European Journal of Operational Research, 2, 429-444.

Chen, T. Y. (2002). Measuring firm performance with DEA and prior information in Taiwan's banks. Applied Economics Letters, 9(3), 201-204.

Chortareas, G., Girardone, C., \& Ventour, A. (2012). Bank supervision, regulation, and efficiency: Evidence from the European Union. Journal of Financial Stability, 8(4), 292-302.

Endri, E. (2015). Macroeconomic and Banking Efficiency Variables in Indonesia. SNEMA-2015. Padang: FE UNP.

Farrell, M. J. (1957). The measurement of productive efficiency. Journal of the Royal Statistical Society, 120(3), 253-290.

Fries, S., \& Taci, A. (2005). Cost efficiency of bank in transition: Evidence from 289 banks in 15 postcommunist countries. Journal of Banking \& Finance, 29(1), 55-81.

Fioderlisi, F., Molyneux. P, \& Marques-Ibanez, D. (2010). Efficiency and risk in European banking (Working Paper No. 1211). European Central Bank. Available at https://ssrn.com/abstract $=1618296$
Garza-García, J. G. (2012). Determinant of bank efficiency in Mexico: A two stage analysis. Applied Economics Letters, 19(17), 1679-1982.

Grigorian, D., \& Manole, V. (2002). Determinants of Commercial Bank Performance in Transition: An Application of Data Envelopment Analysis (Working Paper No. 2850). The World Bank.

Hadad, M. D., Hall, M. J. B., Kenjegalieva, K. A., Santoso, W., Satria, R., \& Simper, R. (2008). Efficiency in Indonesia banking: Recent evidence (Working Paper No. 13). Department of Economics, Loughborough University.

Halkos, G. E., \& Tzeremes, N. G. (2010). The effect of foreign ownership on SMEs performance: An efficiency analysis perspective. Journal of Productivity Analysis, 34(2), 167-180.

Kamarudin, F., Sufian, F., Nassir, A. Md., Anwar N. A. M., \& Hussain, H. I. (2019). Bank efficiency in Malaysia a DEA approach. Journal of Central Banking Theory and Practice, 8(1), 133-162.

La Plante, A. E., \& Paradi, J. C. (2015). Evaluation of bank branch growth potential using data envelopment analysis. Omega, 52, 33-41.

Mahyudin, R. (2005). Study of the Efficiency Level of Commercial Banks in Indonesia and Several Determining Factors (Unpublished doctoral dissertation). Jakarta : Faculty of Economics and Business, University of Indonesia Jakarta.

Mardani, A., Zavadskas, E. K., Streimikiene, D., Jusoh, A., \& Khoshnoudi, M. (2017). A comprehensive review of data envelopment analysis (DEA) approach in energy efficiency. Renewable and Sustainable Energy Reviews, 70, 1298-1322.

Mongid, A. (2016). Business efficiency of the commercial banks in ASEAN. Investment Management and Financial Innovations, 13(1), 67-76.

Mosko, A., \& Bozdo, A. (2015). Modelling the relationship between bank efficiency, capital and risk in Albanian banking system. Procedia Economics and Finance, 39, 319-327.

Paradi, J. C., \& Zhu, H. (2013). A survey on bank branch efficiency and performance research with data envelopment analysis. Omega, 41(1), 61-79.

Řepková, I. (2011). Efficiency Determinants in the Czech Banking Sector. Procedia Economics and Finance, 23, 191 - 196. 
Řepková, I. (2015). Banking efficiency determinants in the Czech Banking sector. Procedia Economics and Finance, 23, 191-196.

Şahin, G., Gökdemir, L., \& Öztürk, D. (2016). Global crisis and its effect on Turkish banking sector: A study with data envelopment analysis. Procedia Economics and Finance, 38, 38-48.

Said, M., \& Ali, H. (2016). An analysis on the factors affecting profitability level of Sharia banking in Indonesia. Banks and Bank Systems, 11(3), 28-36.

Sari, P. Z., \& Saraswati, E. (2017). The determinant of banking efficiency in Indonesia (DEA Approach. Journal of Accounting and Business Education, 1(2), 208-229.

Stewart, C., Matousek, R., \& Nguyen, T. N. (2016). Efficiency in the Vietnamese banking system: A DEA double bootstrap approach. Research in International Business and Finance, 36, 96-111.

Subandi, S., \& Ghozali, I. (2014). A Efficiency Determinant of Banking Industry in Indonesia. Research Journal of Finance and Accounting, 5(3), 18-26.

Sufian, F., \& Noor, M. A. N. M. (2009). The determinants of Islamic banks' efficiency changes: Empirical evidence from the MENA and Asian banking sectors. International Journal of Islamic and Middle Eastern Finance and Management, 2(2), 120-138.

Sufian, F., \& Kamarudin, F. (2015). Determinant of revenue efficiency of Islamic Banks: Empirical evidence Asian countries. International Journal of Islamic and Middle Easthern Finance and Management, 8(1), 36-63.

Titko, J. \& Jureviciene, D. (2014). DEA Application at cross-country benchmarking: Latvian vs Lithuanian banking sector. Procedia - Social and Behavioral Sciences, 110, 1124-1135.

Yildirim, C. (2002). Evolution of banking efficiency within an unstable macroeconomic environment: The case of Turkish commercial banks. Applied Economics, 34, 2289-2301.

Widiarti, A., Siregar, H., \& Andani, T. (2015). The Determinants of Bank's Efficiency in Indonesia. Bulletin of Monetary, Economics and Banking, 18(2), 121-146. 
